\title{
Protective Role of Quercetin on Hippocampus Inflammatory and Oxidative Damage Induced By Monosodium Glutamate in Rats
}

\author{
Shereen Ahmed El-Khateeb ${ }^{1 *}$, Abeer Ramzy Mahmoud ${ }^{1}$, Nahla E. Ibrahem ${ }^{2}$
}

\begin{tabular}{|c|c|}
\hline & ABSTRACT \\
\hline $\begin{array}{l}\text { KEYWORDS } \\
\text { Monosodium glutamate, } \\
\text { Quercetin, } \\
\text { Brain hippocampus, } \\
\text { Molecular mechanism }\end{array}$ & 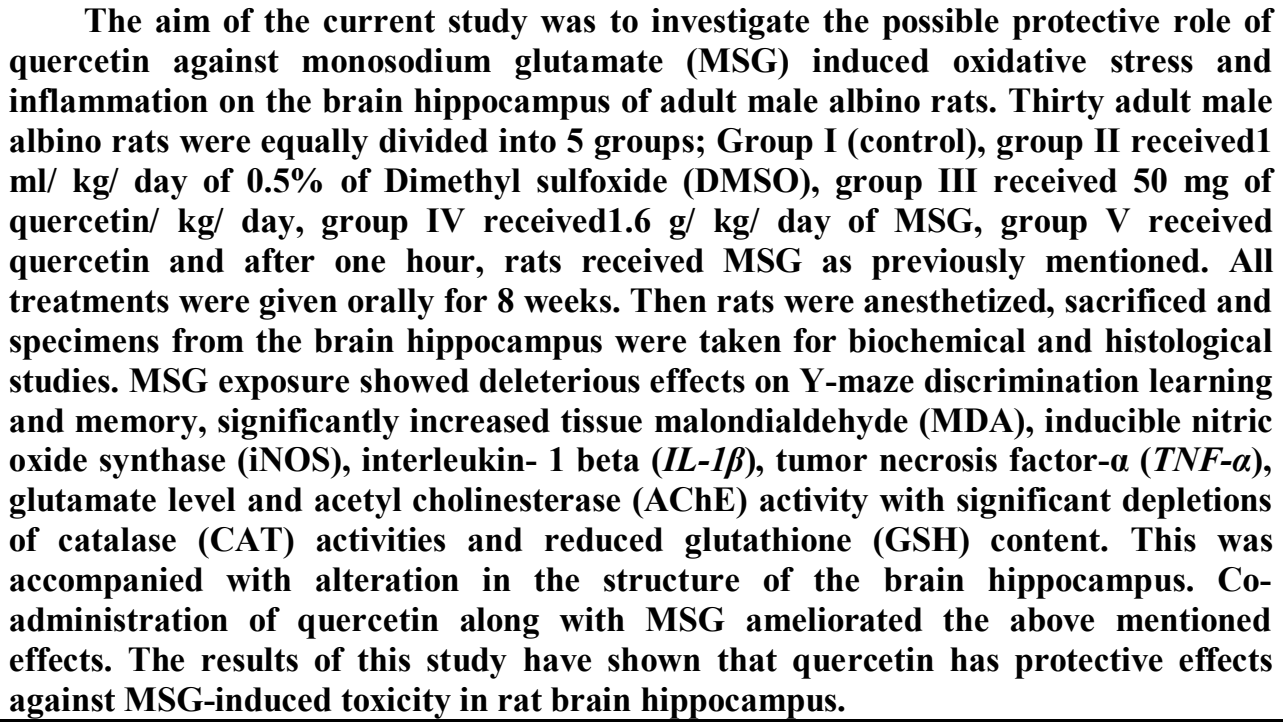 \\
\hline
\end{tabular}

Introduction

Monosodium Glutamate (MSG) is used in commercial foods all over the world. It is found in many different ingredients and processed foods obtainable in every market. It gives a special taste to processed foods (Veni et al., 2010). Therefore, most of canned and fast food as marinated meats, frozen foods, flavored chips, bottled soy, tuna and canned

\footnotetext{
(1) Forensic Medicine and Clinical Toxicology Department, Faculty of Medicine, Zagazig University, Egypt

${ }^{2)}$ Histology and Cell Biology Department, Faculty of Medicine, Zagazig University, Egypt

*The corresponding author:

Forensic Medicine and Clinical Toxicology Department, Faculty of Medicine, Zagazig University, Egypt.
}

and packed soups contain variable concentrations of MSG (Bojanić et al., 2009). The MSG effect was firstly described in 1968 as Chinese restaurant syndrome. Earlier researches reported that MSG has neurotoxic effects (Onishi and Xavier, 2010). It was reported that MSG may influence the memory recovery, cognition as well as capacity to learn (Pilgrim et al., 2012 and Abu-Taweel et al., 2014). Monosodium glutamate induces oxidative stress and disturbance in the antioxidant homeostasis in various organs (Sadek et al., 2016).

Experimental studies reported that toxicity of MSG can be overcome by the substances which could inhibit oxidative damage. Authors investigated the role of 
lycopene, ginger, vitamin E, selenium and propolis to avert the neurotoxic effects of MSG in rats (Sadek et al., 2016; Hussein et al., 2017). Quercetin (3,5,7,30,40pentahydroxyflavone), is one of the flavonoids of polyphenols that is present in fruits, onions, apples and blueberries, black and green tea, citrus fruits and red grapes. Previous studies investigated its beneficial effects on human health and reported that quercetin has antioxidant and anti-inflammatory effects (Mythri et al., 2012; Anand David et al., 2016). Quercetin has been shown to maintain integrity of blood-brain barrier by active oxygen scavenging (Lapi et al., 2012). Also, quercetin has been revealed to be a multitarget therapeutic tool for protecting the brain where it can be a direct inhibitor of monoamine oxidase- $\mathrm{A}$ in nerve cells by targeting mitochondria (Bandaruk et al., 2014).

Based on these findings, the aim of our research was to explore the potential protective role of quercetin against MSG induced oxidative stress and inflammation in the brain hippocampus of adult male albino rats.

\section{Materials and Methods}

\section{Chemicals and Reagents:}

Monosodium glutamate (MSG) (C5H9NO4 Na; purity $>98 \%$ ) was obtained from Al-Dawlya Chemicals Co. (Cairo, Egypt). Quercetin $\left(\mathrm{C}_{15} \mathrm{H}_{10} \mathrm{O}_{7}\right.$, CAS Number: 117-39-5); was provided as a yellow powder ( $\geq 98 \%$ HPLC), and Dimethyl sulfoxide (DMSO); CAS Number: 67-68-5) were obtained from Sigma-Aldrich chemical company (St Louis, MO, USA). The rest of chemicals and reagents were obtained from Sigma-Aldrich (St Louis, MO, USA) and Biodiagnostics (Cairo, Egypt).

\section{Animal treatment and experimental design:}

Thirty adult male Wister albino rats were used. Each rat was 180- 200 grams weight, 7-8 weeks old. They were housed in polypropylene cages and fed standard pellet diet and water, given ad libitum in the departmental animal house of Faculty of Medicine, Zagazig University, Egypt and kept with a 12-h light/dark cycle at controlled temperature $\left(22 \pm 2^{\circ} \mathrm{C}\right)$. This research was done according to the guiding principles for the animal use and care and approved by The Institutional Animal Care and Use Committee, Zagazig University with approval code ZUIACUC/2/F/212/2019.

\section{Experimental design:}

Animals were divided into 5 groups each one has six rats. Total duration of experiment was 8 weeks. Group I served as control (fed on balanced diet and water). Group II received $0.5 \%$ Dimethyl sulfoxide (DMSO) at a daily dose of $1 \mathrm{ml} / \mathrm{kg}$ body weight/ day by oral gavage. Group III received quercetin dissolved in $0.5 \%$ DMSO at a dose $50 \mathrm{mg} / \mathrm{kg}$ body weight /day through oral gavage (El-Beltagi and Ahmed, 2016; Rahvar et al., 2018).

Group IV administered MSG orally as $1.6 \mathrm{~g} / \mathrm{kg}$ body weight/ day (1/10 LD50) where $100 \mathrm{~g}$ of MSG were dissolved in $300 \mathrm{ml}$ tap water and given by oral gavage as $0.95 \mathrm{ml} /$ rat for 8 weeks. The LD50 of MSG in rats is 15$18 \mathrm{~g} / \mathrm{kg}$ bw based on previous studies (Joint FAO/WHO Expert Committee on Food Additives, 1988; Walker and Lupien, 2000). Group V orally received quercetin dissolved in $0.5 \%$ DMSO at a dose $50 \mathrm{mg} / \mathrm{kg}$ body weight and after one hour, rats administered MSG dissolved in tap water at a dose of $1.6 \mathrm{~g} / \mathrm{kg} \mathrm{bw} /$ day.

Cognitive test to assess hippocampal function (Test of Y-Maze Discrimination Learning):

This test was done after 8 weeks of treatment. It was especially designed at the Physiology Department. It consists of three similar arms, which are differentiated by colored spots at their ends. The main mission is to learn a thirsty rat the correct direction 
(right side) in order to acquire a drop of water (Borbély et al., 2013). The rats were thought to have learnt the task when they did 9 of the 10 tests. The rate of learning was evaluated by how many trials needed for obtaining the response. After 24 hours, the test was repeated; memory was measured as the percentage of correct responses.

\section{Sample preparation for biochemical analysis:}

At the end of the experiment, rats were anesthetized then sacrificed by decapitation. The brains were obtained immediately. In each rat; the hippocampus of one hemisphere was removed, isolated, rinsed in ice-cold isotonic saline, dried, homogenized, centrifuged and the resultant supernatant was stored at $-20^{\circ} \mathrm{C}$ until used for biochemical measurements. The hippocampus of the other hemisphere was divided into 2 halves; one half was stored at $-80^{\circ} \mathrm{C}$ and used for real-time polymerase chain reaction (RT-PCR). The other part was used for histopathological examination.

\section{Assessment of Oxidative stresses markers level:}

1. Measurement of lipid peroxidation (LPO) as oxidative stress indicator: Malondialdhyde (MDA) was assessed according to Ohkawa et al. (1979) using commercial available kit.

2. Measurement of reduced glutathione (GSH): Reduced glutathione $(\mathrm{mmol} / \mathrm{g})$ was assessed as described by Beutler et al. (1963) using commercially available kit.

3. Determination of catalase (CAT) enzymes activity: Catalase activity (U/g tissue) was assessed in brain hippocampus according to Aebi (1984). The absorbance was measured at 510 nm.

4. Inducible nitric oxide synthase (iNOS): Nitric oxide assay was done according to
(Montgomery and Dymock, 1961).Total nitrate/nitrite is measured in two steps that first nitrate is converted to nitrite. Secondly, nitrite is converted to a deep purple azo compound that has a bright reddish-purple color.

\section{Determination of Acetylcholinesterase (AChE; EC 3.1.1.7.) activity in hippocampus}

Acetyl cholinesterase (AChE) activity was measured as done by Ellman and Callaway (1961). The activity was expressed as $\mu$ moles of acetylthiocholine hydrolyzed/ $\mathrm{min} / \mathrm{mg}$ tissue.

\section{Determination glutamate Level in hippocampus}

Glutamate measurement were done using rat glutamate enzyme linked immunesorbent assay (ELISA) kit (No: MBS047402, MyBioSource, Canada) by a microplate reader (Tecan, Infinite 200 PRO, Switzerland) at 450 $\mathrm{nm}$. Glutamate levels were assessed by the standard curve as reported by the manufacturer.

Analyses of Gene Expression of ILI- $\beta$ and $T N F-\alpha$ by Real Time PCR

Total RNA was extracted from brain hippocampus homogenate using a Qiagen RNA isolation kit (RNeasy, Qiagen Ltd, Crawley, West Sussex, UK) according to the manufacturer's protocol. The total RNA was quantified by the measured absorbance at 260 $\mathrm{nm}$ in a spectrophotometer. After that, RNA is converted into complementary DNA (cDNA) by reverse transcriptase (QuantiTect Reverse Transcription Kit, QIAGEN, \# 205310, Germany). This extracted RNA was used for assessment of expression of ILI $\beta$ and TNF- $\alpha$. All the specimens were run in duplicates. PCR amplification consisted of 40 cycles of denaturation at $95^{\circ} \mathrm{C}$ for $10 \mathrm{~s}$, annealing at $55^{\circ} \mathrm{C}$ for $10 \mathrm{~s}$, and extension at $72^{\circ} \mathrm{C}$ for $20 \mathrm{~s}$. The primers were designed by the web based tool, Primer 3 (http://www-genome. 
wi.mit.edu/cgi-bin/primer/ primer3_ www.cgi) based on the published rat sequence. The sequence of the primers used is as follow: $I L$ $1 \beta$ forward, 5'CACCTCTCAAGCAGAGCACAG $-3{ }^{\prime} ; L-1 \beta$ reverse, 5 GGGTTCCATGGTGAAGTCAAC-3; TNF- $\alpha$ forward 5 AAATGGGCTCCCTCTCATCAGTTC 3 $T N F-\alpha \quad$ reverse, $5^{\circ}$ TCTGCTTGGTGGTTTGCTACGAC- $\quad 3$; glyceraldehyde 3-phosphate dehydrogenase (GAPDH) forward, GTATTGGGCGCCTGGTCACC3 ; GAPDH reverse, $55^{\prime}$ CGCTCCTGGAAGATGGTGATGG3`. The amount of cDNA in the reactions was normalized with an internal control, the constitutively expressed gene glyceraldehyde 3-phosphate dehydrogenase (GAPDH). Relative gene expression was calculated from the formula: $2 \Delta \mathrm{CT} ;(\Delta \mathrm{CT}=\mathrm{CT} \mathrm{GAPDH}-\mathrm{CT}$ target).

\section{Histopathological studies:}

Specimens $(1 \mathrm{~cm}$ thick) were fixed in $10 \%$ buffered formalin solution and processed to obtain paraffin sections of $5 \mu \mathrm{m}$ thickness. The sections were stained with haematoxylin and eosin (Bancroft and Gamble, 2008).

\section{Morphometric analysis:}

The thickness of the granular cell layer in the dentate gyrus and the pyramidal cell layer in CA1, CA1 and CA3 were measured. Lines were drawn vertically; the lines were then measured by the software. Moreover, the surface area of granular cells in the dentate gyrus and pyramidal cells in CA1, CA2 and CA3 were measured. For each animal, five non-overlapping high-power fields $(\times 400)$ from five different sections were randomly chosen. Five separate readings from each of the photos taken were recorded and the mean was calculated for each specimen. All data have been collected using a Leica Qwin 500 image analyzer computer system (UK) at the Histology and Cell Biology Department, Faculty of Medicine, Cairo University.

\section{Statistical analysis:}

Data were analyzed by Statistical Package of Social Science (SPSS), software version 20 (SPSS Inc., 2011). Data were normally distributed and summarized as mean \pm Standard deviation. Differences among the groups were analyzed through One way analysis of variance (ANOVA) followed by post-hoc Tukey HSD Test for inter-group comparisons difference.

\section{Results}

\section{Y- maze test:}

Administration of MSG had affected Ymaze discrimination learning and memory in rats as the number of trials needed to learn was more than that of control $(p<0.01)$, the duration of all responses was more than the control $(p<0.01)$. The proper rate one day after was less than the control denoting lack of ability to learn and deteriorated memory. Rats treated with MSG and quercetin showed considerably enhanced learning and memory in Y- maze test $(p>0.01)$ (Table 1). 
Table (1): Comparison of Y-maze discrimination learning and memory in different groups.

\begin{tabular}{|l|c|c|c|}
\hline \multicolumn{1}{|c|}{$\begin{array}{c}\text { Groups } \\
(\mathbf{n = 6})\end{array}$} & $\begin{array}{c}\text { Number of training } \\
\text { sessions } \\
\text { Mean } \pm \text { SD }\end{array}$ & $\begin{array}{c}\text { Duration } \\
\text { (sec) }\end{array}$ & $\begin{array}{c}\text { \% of Correct response } \\
\text { after 24 hours } \\
\text { Mean } \pm \text { SD }\end{array}$ \\
\hline Group I (negative control) & $16.5 \pm 1.37$ & 910 & $72 \pm 1.2$ \\
\hline Group II (DMSO) & $16.5 \pm 1.1$ & 912 & $71 \pm 2.3$ \\
\hline Group III (Quercetin) & $16.17 \pm 1.04$ & 915 & $71 \pm 1.6$ \\
\hline Group IV (MSG) & $24.7 \pm 2.8^{\#}$ & 1800 & $63 \pm 2.4$ \\
\hline $\begin{array}{l}\text { Group V (Quercetin+ } \\
\text { MSG) }\end{array}$ & $18.3 \pm 1.5^{\# \#}$ & 950 & $73 \pm 1.4$ \\
\hline \multicolumn{1}{|c|}{$p$ - value } & $p<0.01$ \\
\hline
\end{tabular}

SD: standard deviation; $\mathrm{n}$ : number; \# $p<.01$ is significant as compared with control group; \#\# $p<.01$ is significant as compared with MSG treated group; sec: seconds MSG: monosodium glutamate; DMSO: Dimethyl sulfoxide

\section{Assessment of oxidative stress in treated groups:}

Administration of MSG elevated MDA in hippocampus $(p<0.01)$. A decrease in GSH content, and CAT activity was observed in MSG administered rats as compared to control ones. Co-administration of quercetin with MSG obviously attenuated oxidative stress by ameliorating MDA and increasing GSH content and CAT activity in hippocampus as compared to MSG group $(p<0.01)$. Regarding iNOS level, it was increased in MSG treated rats in comparison with control group. Quercetin co administration with MSG decreased the level of iNOS $(p<0.01)$ (Table 2$)$.

Table (2): Comparison of the antioxidant status in brain hippocampus of different Studing groups.

\begin{tabular}{|c|c|c|c|c|}
\hline \multirow[t]{2}{*}{$\begin{array}{c}\text { Groups } \\
(n=6)\end{array}$} & $\begin{array}{c}\text { MDA } \\
\text { (nmol/g tissue) }\end{array}$ & $\begin{array}{c}\text { GSH } \\
\text { (nmol/g tissue) }\end{array}$ & $\begin{array}{c}\text { CAT } \\
(\mathrm{U} / \mathrm{g} \text { tissue })\end{array}$ & $\begin{array}{c}\text { iNOS } \\
(\mathrm{nmol} / \mathrm{g})\end{array}$ \\
\hline & \multicolumn{4}{|c|}{ Mean \pm SD } \\
\hline $\begin{array}{l}\text { Group I } \\
\text { (negative control) }\end{array}$ & $11.48 \pm 1.17$ & $4.64 \pm 0.37$ & $16.5 \pm 0.84$ & $21.50 \pm 0.97$ \\
\hline $\begin{array}{l}\text { Group II } \\
\text { (DMSO) }\end{array}$ & $11.92 \pm 1.17$ & $4.64 \pm 0.37$ & $16.38 \pm 1.7$ & $21.14 \pm 1.17$ \\
\hline $\begin{array}{l}\text { Group III } \\
\text { (Quercetin) }\end{array}$ & $10.23 \pm 0.91$ & $5.18 \pm 0.41$ & $17.33 \pm 2.1$ & $20.70 \pm 1.00$ \\
\hline $\begin{array}{l}\text { Group IV } \\
\text { (MSG) }\end{array}$ & $16.42 \pm 2.35 \#$ & $2.59 \pm 0.62^{\#}$ & $11.62 \pm 2.1^{\#}$ & $\begin{array}{c}35.44 \pm \\
3.16^{\#} \\
\end{array}$ \\
\hline $\begin{array}{l}\text { Group V } \\
\text { (Quercetin+ MSG) }\end{array}$ & $10.8 \pm 1.7 \# \#$ & $4.81 \pm 0.57^{\# \#}$ & $18.14 \pm 2.4^{\# \#}$ & $\begin{array}{l}18.40 \pm \\
0.58^{\#} \\
\end{array}$ \\
\hline$p$-value & & $p<0$ & & \\
\hline
\end{tabular}

$\mathrm{SD}$ : standard deviation, $\mathrm{n}$ : number of rats in each group; \# $\mathrm{p}<.01$ is significant vresus control group; \#\# $\mathrm{p}<.01$ is significant versus MSG treated group; MDA: malondialdehyde; GSH: reduced glutathione; CAT: catalase; iNOS: inducible nitric oxide synthase,MSG: monosodium glutamate; DMSO: Dimethyl sulfoxide 
Assessment of AChE activity and glutamate level in brain hippocampus of treated groups

Rats treated with MSG showed a significant increase in AChE activity $(p<0.01)$ as compared to control group. However, administration of quercetin along with MSG revealed reduction in AChE activity $(p<0.01)$ as compared to MSG treated rats (Figure 1). Assessment of glutamate neurotransmitter showed significant elevation $(p<0$. 01) in MSG treated group versus ordinary control. However, supplementation with quercetin returned glutamate level in the brain to almost normal (Figure 2).

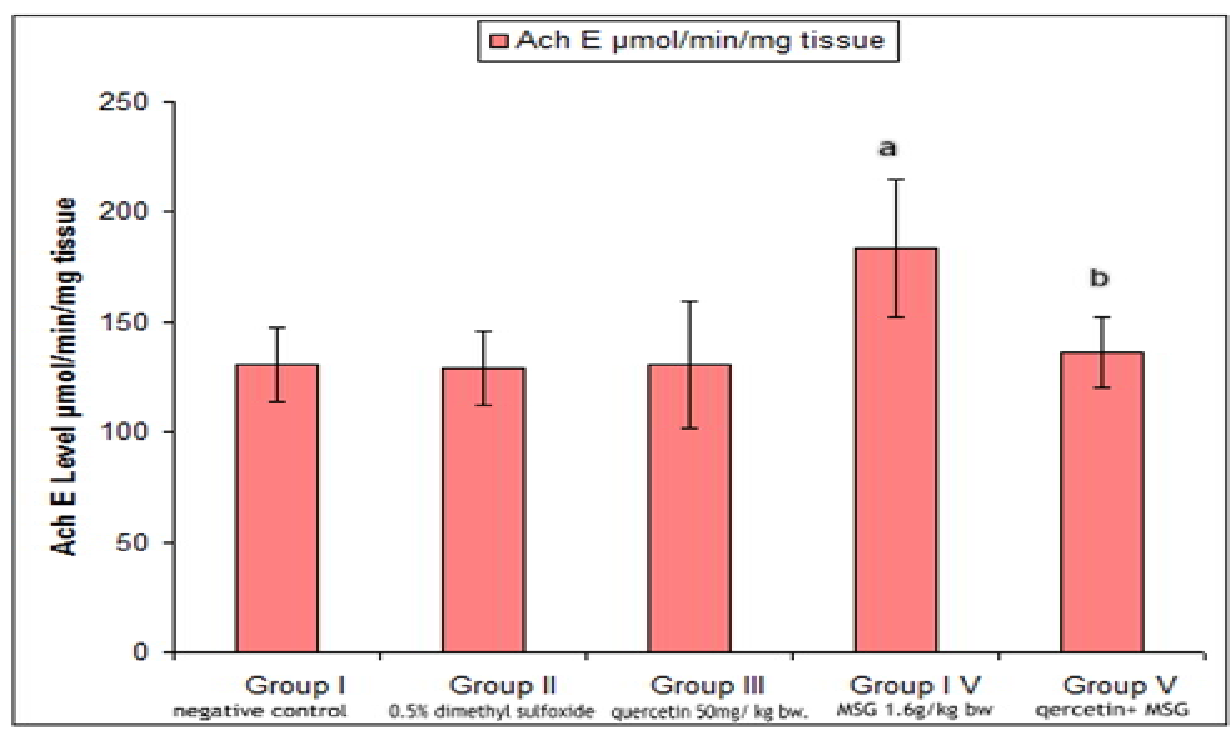

Fig. (1): Acetyl cholinesterase (Ach E) level in the studied groups; a: significant as compared with control group; b: significant as compared with monosodium glutamate (MSG) treated group.

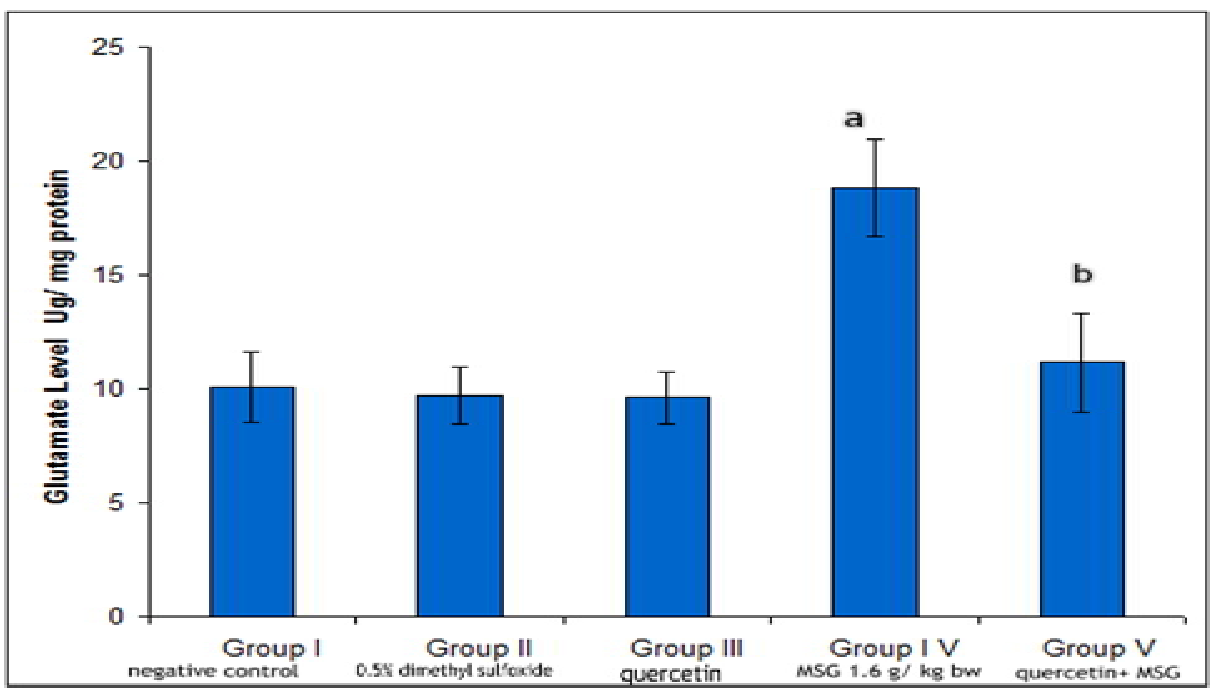

Fig. (2): Glutamate level in the studied groups; a: significant as compared with control group; b: significant as compared with monosodium glutamate (MSG) treated group. 
mRNA expression of $I L-1 \beta-, T N F-\alpha$

Administration of MSG for 8 weeks revealed increasing in mRNA expression of pro-inflammatory cytokines $I L-1 \beta, \quad T N F-\alpha$. This was reduced by administration of quercetin along with MSG (Figure 3).

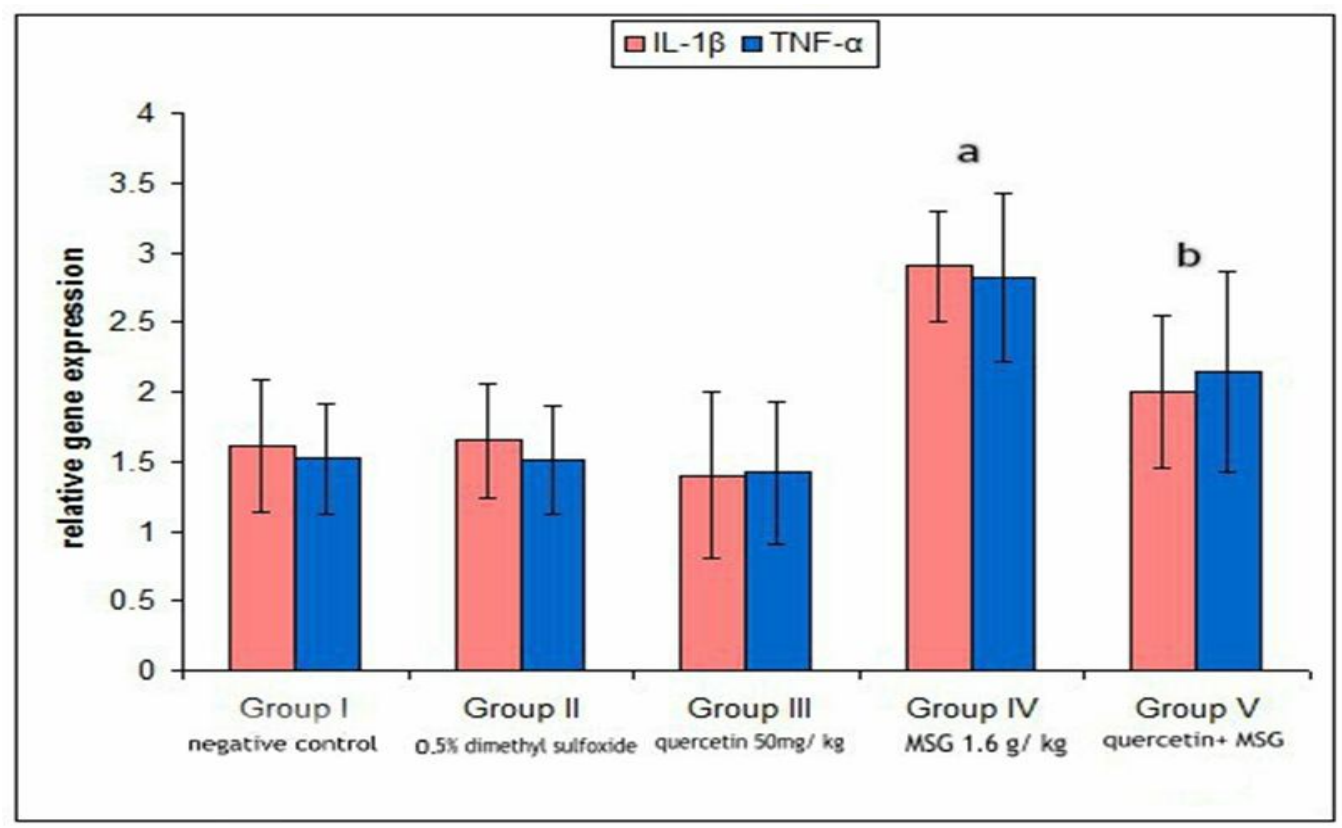

Fig. (3): Tissue interleukin (IL-1 $\beta)$, tumor necrosis factor- $\alpha(T N F-\alpha$. a: significant as compared with control group; b: significant as compared with monosodium glutamate (MSG) treated group.

\section{Histological examination}

Histological examination of hematoxylin and eosin stained sections of brain hippocampus taken from the control, DMSO and quercetin groups showed normal structure which is formed of Cornu Ammonis (CA) parts as CA1, CA2, CA3 \& CA4 regions and $\mathrm{C}$ shape dentate gyrus (DG) enclosing $\mathrm{CA} 4$
(Figure 4A). Dentate gyrus is formed of three layers; the granular layer contains granule cells, the molecular layer and the polymorphic layer (Figure $4 \mathrm{~B}$ ). The CA1 and CA2 formed of zone of closely packed small pyramidal cells, CA3 and CA4 formed of zone of large pyramidal triangular cells (Figures $4 \mathrm{C}, \mathrm{D}$, and E). 


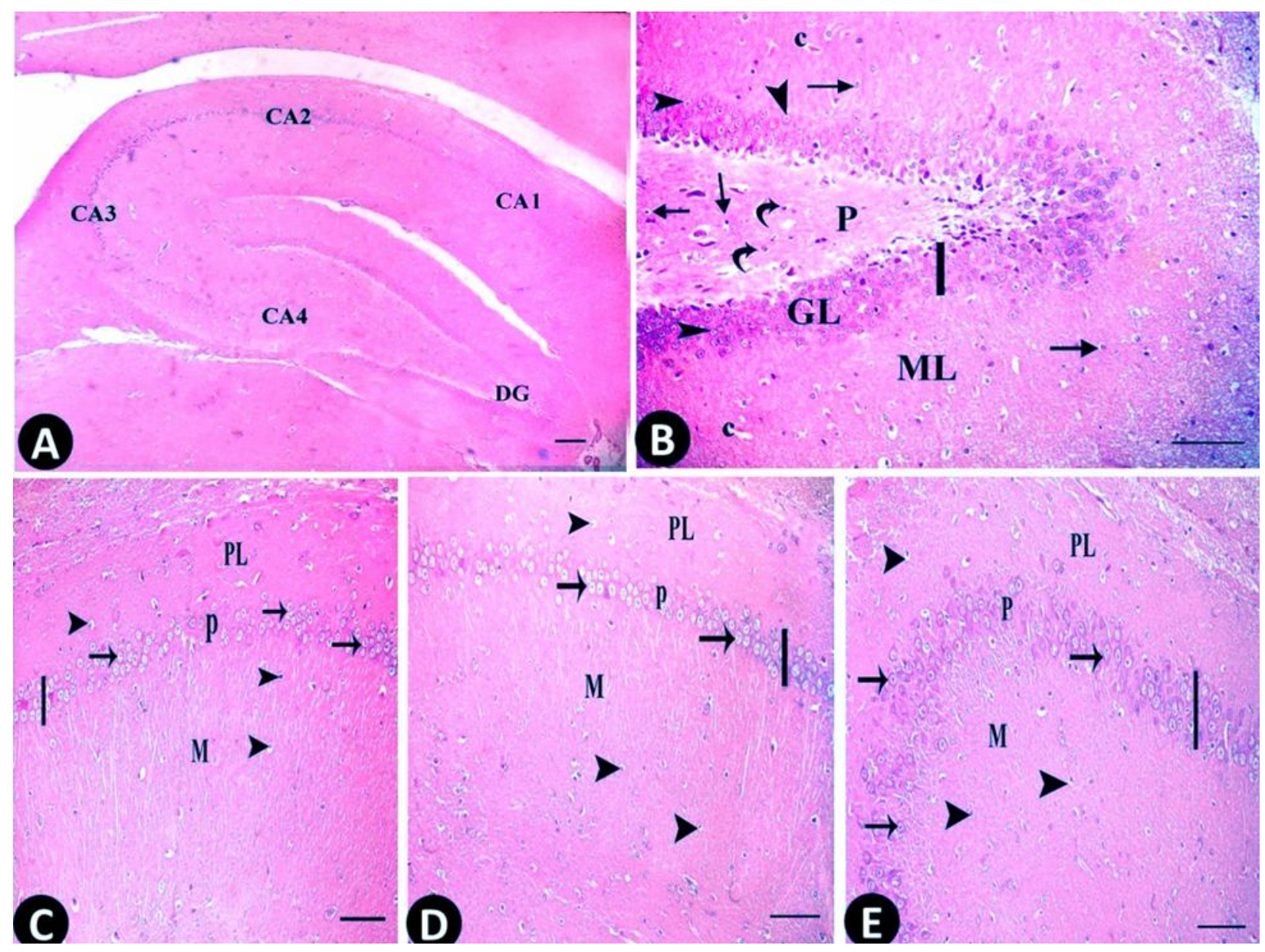

Fig. (4): Sections of the control hippocampus of control group. (A): Cornu Ammonis (CA) parts as (CA1), (CA2), (CA3) \& (CA4) regions and dentate gyrus (DG) $(\mathrm{H} \& \mathrm{E} \times 40)$. (B): Dentate gyrus with three layers; granular layer (GL) containing granule cells (arrow head) and the vertical line (|) represents its thickness, the molecular layer (ML) contains neuroglial cells (arrow) and blood capillaries (c) and polymorphic layer (PL) reveals pyramidal (curved arrow) and neuroglial cells (arrow). (C,D \&E) showing CA1, CA2 and CA3 areas. The vertical line $(\mid)$ represents the thickness of the pyramidal cell layer $(H \& E \times 200)$.

Monosodium glutamate treated group showed alteration in the structure of dentate gyrus where granule and small pyramidal cells showed small dark stained nuclei. Granular and polymorphic layers showed areas of cell loss, vacuolation, dilated blood capillaries and increased neuroglial cells (Figure 5 A). Morphometric analysis revealed decrease in the mean surface area of granular cells and mean thickness of granular layer in comparison to control group $(p<0.001)$
(Tables 3 and 4). Regarding CA1, CA2, CA3 areas, they showed severely damaged pyramidal cells in the form of pyknotic, shrunken, darkly stained nuclei, vacuolation, and dilated blood vessels (Figures $5 \mathrm{~B}, \mathrm{C}$ and D). Morphometric analysis revealed statistically significant $(\mathrm{p}<0.001)$ decrease in surface area of pyramidal cells and thickness of pyramidal layer in CA1, CA2 and CA3 of MSG group $(p<0.001)$ as compared to control (Tables 3 and 4). 


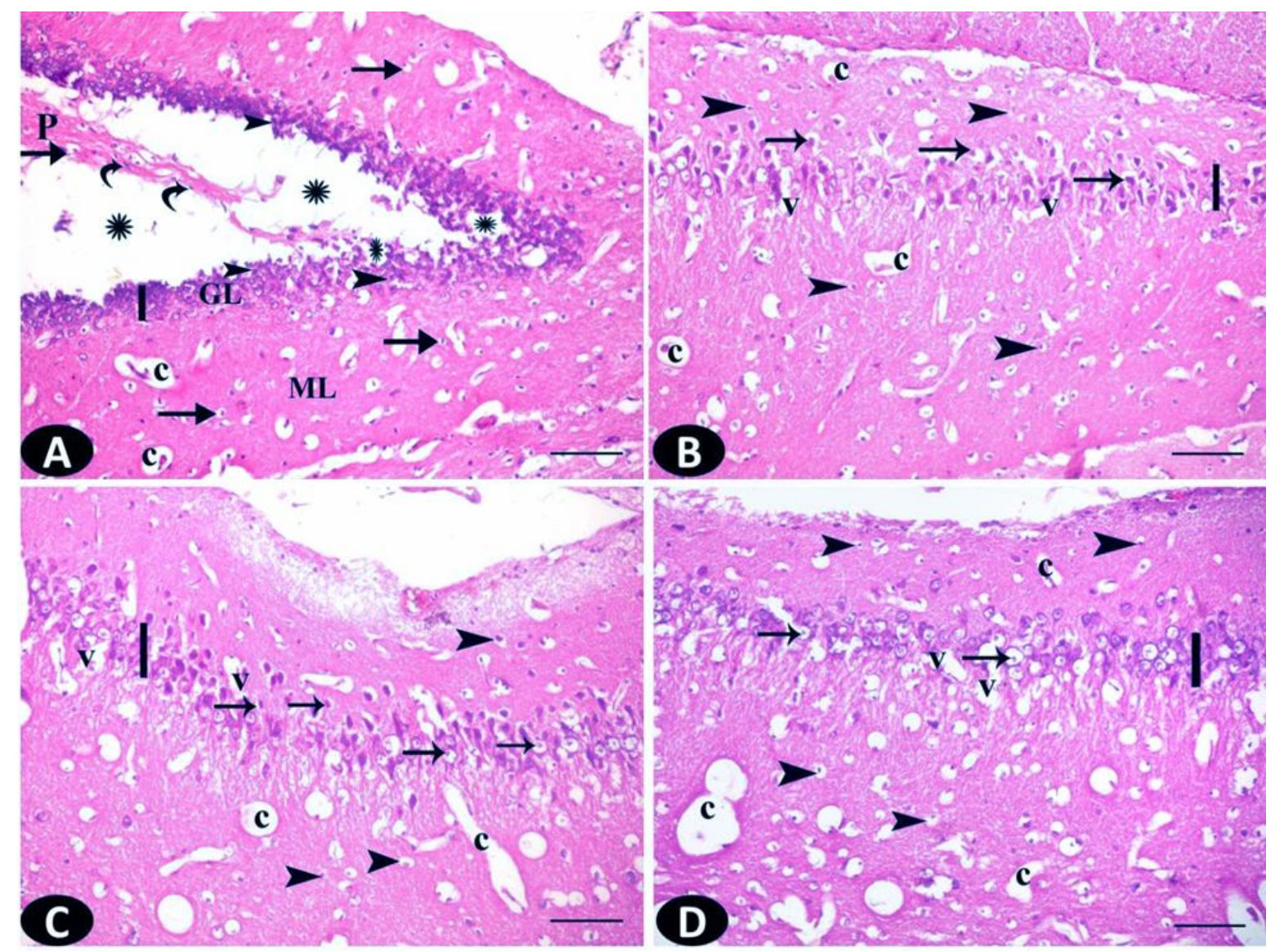

Fig. (5): Sections from hippocampus of rats received monosodium glutamate (MSG) 1.6 $\mathrm{g} / \mathrm{kg}$. bw/ day showing (A): Dentate gyrus reveals granule cells and pyramidal cells with small dark stained nuclei (arrow head)\& (curved arrow) respectively with areas of cell loss $(*)$, vacuolation (v), dilated blood capillaries (c) and neuroglial cells (arrow) are observed. (B) CA1 area, (C):CA2 area, (D): CA3 area, all showing many of pyramidal cells shrunken with darkly stained nuclei and wide peri-cellular spaces (arrow). (H\&E×200); ML; molecular layer; GL; granular layer.

Examination of H\&E stained sections of rats treated with quercetin and MSG revealed nearly normal hippocampus. Dentate gyrus showed granule cells with vesicular nuclei and reduced vacuolation, while there were still small dark nuclei in some granule cells. The picture was near to normal regarding CA1, $\mathrm{CA} 2$ and $\mathrm{CA} 3$ areas (Figures 6; B, C and D).
Morphometric analysis revealed statistically significant $(p<0.001)$ increase in the mean surface area of granule cells and pyramidal cells, increase mean thickness of granular layer of dentate gyrus pyramidal layer of CA1, $\mathrm{CA} 2$ and $\mathrm{CA} 3$ than in the MSG group $(p<0.001)$ (Tables 3 and 4$)$. 


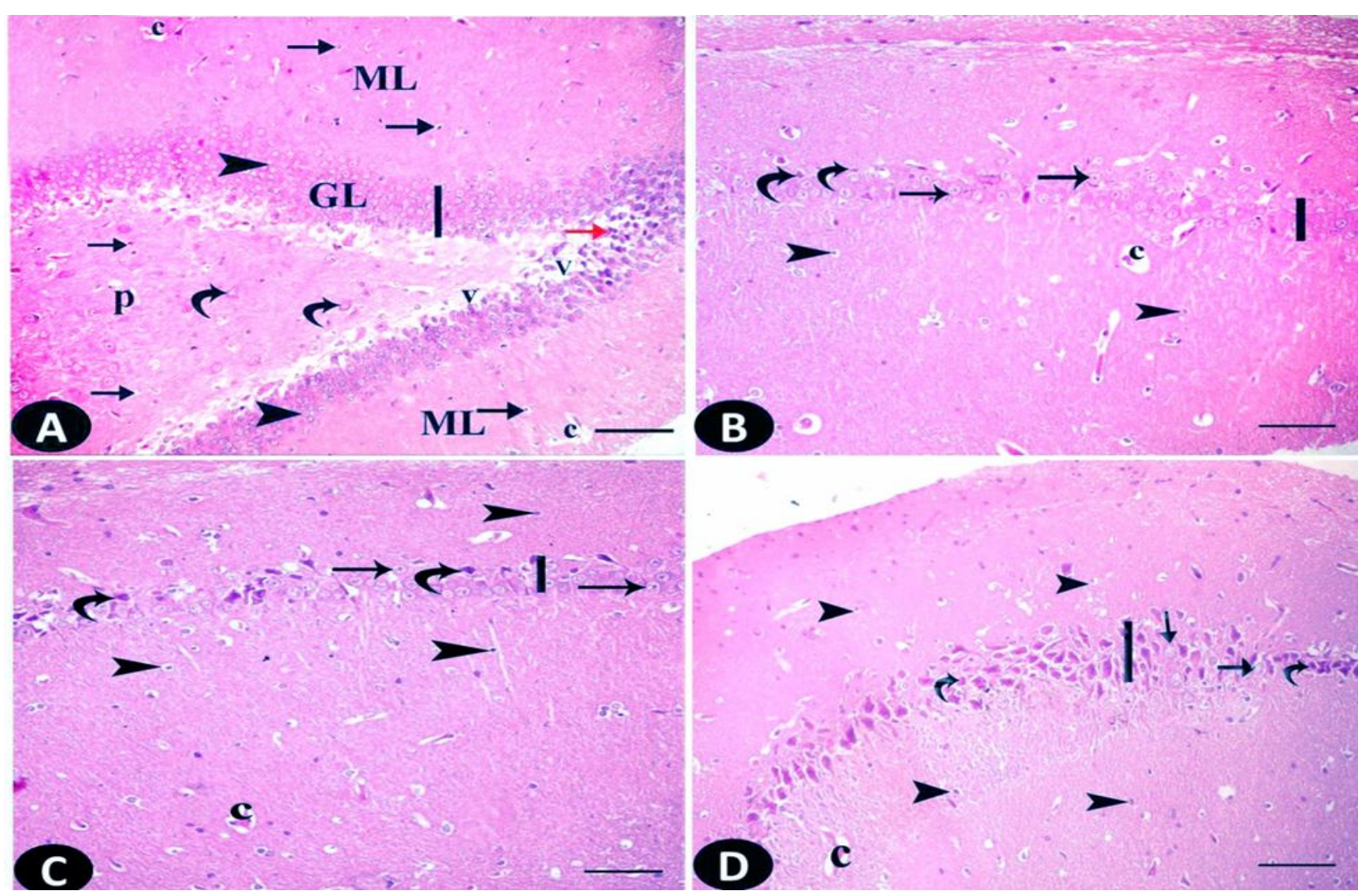

Fig. (6): Sections from hippocampus of rats received monosodium glutamate (MSG) at dose $1.6 \mathrm{~g} / \mathrm{kg}$. bw/ day and quercetin at dose $50 \mathrm{mg} / \mathrm{kg}$. bw/ day showing (A): dentate gyrus reveals apparently normal structure. Granular layer (GL) showing normal cells (arrow head) while others have small dark nuclei (red arrow). (B): CA1 area, (C): CA2 area and (D): CA3 area look more organized (H\&E×200), (arrow): normal pyramidal cells; (curved arrow): cells with darkly stained nuclei, (c): dilated blood capillaries. ML; molecular layer; GL; granular layer.

Table (3): Comparison of the mean surface area of pyramidal cells $\left(\mu \mathrm{m}^{2}\right)$ in CA1, CA2 and CA3 and granular cells in dentate gyrus of different studing groups.

\begin{tabular}{|c|c|c|c|c|c|}
\hline \multirow[b]{2}{*}{$\begin{array}{c}\text { Surface area } \\
(\text { Mean } \pm \text { SD) }\end{array}$} & \multicolumn{5}{|c|}{ Groups $(n=6)$} \\
\hline & $\begin{array}{c}\text { Group I } \\
\text { (negative } \\
\text { control) }\end{array}$ & $\begin{array}{l}\text { Group II } \\
\text { (DMSO) }\end{array}$ & $\begin{array}{l}\text { Group III } \\
\text { (Quercetin) }\end{array}$ & $\begin{array}{l}\text { Group IV } \\
\text { (MSG) }\end{array}$ & $\begin{array}{c}\text { Group V } \\
\text { (Quercetin+ MSG }\end{array}$ \\
\hline CA1 & $\begin{array}{l}227.89 \\
\pm 26.70 \\
\end{array}$ & $226.54 \pm 29.50$ & $\begin{array}{c}228.41 \\
\pm 28.30\end{array}$ & $99.71 \pm 16.15^{\#}$ & $\begin{array}{c}218.6 \\
\pm 25.6^{\# \#}\end{array}$ \\
\hline CA2 & $\begin{array}{c}223.42 \\
\pm 27.80\end{array}$ & $\begin{array}{l}222.71 \\
\pm 25.6\end{array}$ & $\begin{array}{c}224.13 \\
\pm 29.9\end{array}$ & $107.8 \pm 18.75^{\#}$ & $\begin{array}{c}213.5 \\
\pm 29.07^{\# \#}\end{array}$ \\
\hline CA3 & $\begin{array}{r}221.70 \\
\pm 24.09\end{array}$ & $\begin{array}{l}223.12 \\
\pm 21.05\end{array}$ & $\begin{array}{r}222.50 \\
\pm 23.20\end{array}$ & $\begin{array}{c}113.34 \\
\pm 18.41^{\#}\end{array}$ & $\begin{array}{l}198.5 \\
\pm 25^{\# \#}\end{array}$ \\
\hline Dentate gyrus & $\begin{array}{r}148.96 \\
\pm 15.16\end{array}$ & $146.71 \pm 15.95$ & $147.51 \pm 16.62$ & $50.73 \pm 8.99^{\#}$ & $116.9 \pm 14.74^{\# \#}$ \\
\hline$p$-value & \multicolumn{5}{|c|}{$p<0.01$} \\
\hline
\end{tabular}

SD: standard deviation; $\mathrm{n}$ : number of rats; \# $\mathrm{p}<.001$ is significant versus control; \#\# $p<.001$ is significant versus $\mathrm{MSG}$ treated group; CA: Cornu Ammonis; MSG: monosodium glutamate 
Table (4): Comparison of mean thickness in pyramidal layer $(\mu \mathrm{m})$ in CA1, CA2 and CA3 and granular layer (um) in dentate gyrus of different groups of the study.

\begin{tabular}{|c|c|c|c|c|c|}
\hline \multirow[b]{2}{*}{$\begin{array}{l}\text { Thickness } \\
\text { Mean } \pm \text { SD }\end{array}$} & \multicolumn{5}{|c|}{ Groups $(n=6)$} \\
\hline & $\begin{array}{c}\text { Group I } \\
\text { (negative } \\
\text { control) } \\
\end{array}$ & $\begin{array}{l}\text { Group II } \\
\text { (DMSO) }\end{array}$ & $\begin{array}{c}\text { Group III } \\
\text { (Quercetin) }\end{array}$ & $\begin{array}{c}\text { Group IV } \\
\text { (MSG) }\end{array}$ & $\begin{array}{c}\text { Group V } \\
\text { (Quercetin+ } \\
\text { MSG }\end{array}$ \\
\hline CA1 & $\begin{array}{c}119.05 \\
\pm 18.76\end{array}$ & $\begin{array}{c}118.14 \\
\pm 20.56\end{array}$ & $\begin{array}{c}120.31 \\
\pm 20.24 \\
\end{array}$ & $\begin{array}{c}68.33 \\
\pm 10.07 \# \\
\end{array}$ & $\begin{array}{c}115.9 \\
\pm 19.40 \# \# \\
\end{array}$ \\
\hline $\mathrm{CA} 2$ & $\begin{array}{r}126.25 \\
\pm 25.63 \\
\end{array}$ & $\begin{array}{r}125.84 \\
\pm 21.15 \\
\end{array}$ & $\begin{array}{r}126.97 \\
\pm 22.98 \\
\end{array}$ & $\begin{array}{c}69.70 \\
\pm 11.26 \# \\
\end{array}$ & $\begin{array}{l}120.21 \\
\pm 20.18 \\
\end{array}$ \\
\hline CA3 & $\begin{array}{r}134.46 \\
\pm 17.51 \\
\end{array}$ & $\begin{array}{r}134.46 \\
\pm 17.51 \\
\end{array}$ & $\begin{array}{r}134.46 \\
\pm 16.11 \\
\end{array}$ & $\begin{array}{c}70.82 \\
\pm 9.62 \# \\
\end{array}$ & $\begin{array}{c}115.23 \\
\pm 14.26 \# \# \\
\end{array}$ \\
\hline $\begin{array}{c}\text { Dentate } \\
\text { gyrus }\end{array}$ & $\begin{array}{c}132.66 \pm \\
19.14 \\
\end{array}$ & $\begin{array}{c}132.66 \pm \\
18.14 \\
\end{array}$ & $\begin{array}{c}132.66 \pm \\
18.21 \\
\end{array}$ & $60.75 \pm 10.01 \#$ & $\begin{array}{l}126.84 \pm \\
15.54 \# \#\end{array}$ \\
\hline$p$-value & \multicolumn{5}{|c|}{$p<0.01$} \\
\hline
\end{tabular}

SD: standard deviation; $\mathrm{n}$ : number of rats; \# $\mathrm{p}<.001$ is significant versus control; \#\# $p<.001$ is significant versus MSG treated group; CA: Cornu Ammonis; MSG: monosodium glutamate

\section{Discussion}

Monosodium glutamate activates of both ionotropic and metabotropic glutamate receptors (iGluR and mGluR) in the central nervous system. Over activation of these receptors had led to excitotoxicity and neuronal death (Pavlovic et al., 2009).

Quercetin was found to have the capacity to crosses the blood-brain barrier (Paulke et al., 2006). Further, the role of quercetin against MSG induced brain hippocampus toxicity was not well researched. The objective of this research was to assess the possible protective role of quercetin against MSG induced oxidative stress and inflammation on the brain hippocampus of adult male albino rats.

In the present study, administration of MSG induced profound negative effects in the brain hippocampus. This was assured from enhanced lipid peroxidation, pro-inflammatory cytokines $(I L-1 \beta, T N F-\alpha)$, increased glutamate level and AChE activity associated with concomitant decrease in antioxidant defense system in brain hippocampus. Quercetin coadministration along with MSG attenuated MSG induced neurotoxicity through modulation of oxidative damage and inflammation in brain hippocampus.

Assessment of oxidative stress markers in the present study revealed a significant increase in the MDA level and reduction in the total GSH content and CAT antioxidant enzyme activity in the brain hippocampus of MSG treated rats. Moreover iNOS level was increased. On the same context, Shivasharan et al. (2013) and Hussein et al. (2017) reported enhanced oxidative stress in the kidney and brain of rats after MSG intake. GSH depletion indicates tissue degeneration (Andersen, 2004; Mahmoud and Hussein, 2014). Catalase (CAT) has a basic role in getting ride of hydrogen peroxide (Singh et al., 2008; Bjorklund and Chirumbolo, 2017). The histopathological results of this research confirmed the negative effects of MSG on the brain hippocampus where MSG treated rats showed alteration in the structure of dentate 
gyrus, CA1, CA2 and CA3 areas. Hashem et al. (2012) reported that MSG administration induced degeneration in neurons and astrocytes in cerebellar cortex of rats. Also, Dief et al. (2014) evaluated the neurodegenerative effect of MSG and illustrated that cyclic AMP-activated protein kinase (AMPK) level was reduced and (Fas ligand) that mediate apoptosis showed two folds increase in the hippocampus of MSG treated rats.

Quercetin is a naturally occurring flavonoid compound that is characterized by the presence of multiple phenol rings, $\mathrm{C}$ to $\mathrm{C}$ double bonds and hydroxyl groups (Myhrstad et al., 2002). The hydroxyl groups are critical for antioxidant activity, and scavenge free radicals and ROS by donation of a proton (Justino et al., 2009). Co-administration of quercetin along with MSG ameliorated oxidative stresses, decreased MDA level, produced an inhibitory effect on iNOS and restored the antioxidant enzymes confirming its antioxidant property. These protective effects were assured by histopathological examination of the brain hippocampus. Coadministration of quercetin preserved hippocampal cell architecture. These results can be matched with Kanter et al. (2016) who concluded that quercetin inhibited neuronal apoptosis, and raised antioxidant enzyme activity of the hippocampal tissue resulted from cadmium toxicity. The results of the present study were consistent with preceding studies (Sharma et al., 2013; Sharma et al., 2016). Yang et al. (2013) stated that pretreatment of mouse hippocampal neuronal cells (HT22) with quercetin significantly inhibited formation of reactive oxygen species by about $77.89 \%$ compared with that of glutamate-treated cells. Also, Bao et al. (2017) reported that PC-12 cells pretreated with quercetin showed improved cell viability, decreased H2O2-inhanced ROS formation and mitigated lipoperoxidation of cell membranes.
The present results showed increased levels of $I L-1 \beta, T N F-\alpha$ in brain hippocampus of MSG treated rats. This was in line with Khalil and Khedr (2016) who stated that coadministration of quercetin along with MSG induced an anti-inflammatory response through significant decrease in mRNA expression of pro-inflammatory cytokines $I L$ $1 \beta, T N F-\alpha$. This also was in agreement with previous studies where quercetin decreased the formation of iNOS, COX-2, PGE2, and $I L-1 \beta$ (Kang et al., 2013; Vargas-Restrepo et al., 2018).

Stimulation of glutamate receptors may cause excitation and death of neurons (Zhou and Danbolt, 2014). In this study, MSG administration was found to increase the level of glutamate in the brain hippocampus of treated rats. This increase was consistent with the outcomes of (Hussein et al., 2017). On the other hand, quercetin supplementation along with MSG restored the brain glutamate level to nearly normal. Lu et al. (2013) suggested that quercetin suppress glutamate release and linked this to the reduction in presynaptic voltage-dependent $\mathrm{Ca}^{2+}$ entry and to the inhibition of protein kinase $\mathrm{C}$ and protein kinase A activity.

As a neurotransmitter, acetyl choline is involved in behavior, learning, memory and neurodegeneration. The results of this study have shown that MSG enhanced hippocampus AChE activity in rats. Increased AChE activity may reduce cholinergic neurotransmission effect secondary to reduction in acetyl choline level in the synaptic cleft that might enhance progressive cognitive deterioration (Khalil and Khedr, 2016). Abu-Taweel et al. (2014) interpreted the enhanced $\mathrm{AChE}$ activity by oxidative stress. In this research, co-administration of quercetin together with MSG reduced $\mathrm{AChE}$ activity. Moreover, quercetin ameliorated oxidative stresses. In a research to assess the impact of quercetin on toxicity caused by cadmium, Abdalla et al. (2013) noted that quercetin inhibited the rise in AChE activity. 
Administration of MSG showed negative effects on Y-maze discrimination learning and memory in rats. This was coincided with Zhang et al. (2012). The hippocampus has a basic function in controlling memory and learning functions (Compton, 2004). The impairment in working memory seen at MSG treated rats was explained secondary to the combined effect of slight elevation of glutamate and glutamine coupled with increased oxidative stress (Onaolapo et al., 2016). Other studies have shown that the memory impairment might be through inhibition of the cholinergic system (Park et al., 2000; Perez-Lloret and Barrantes, 2016). On the same context, the results of our study revealed increased oxidative stress, $\mathrm{AChE}$ activity and glutamate level in MSG-treated group versus the normal control.

Quercetin is considered as a cognitive enhancer in traditional medicine (Suganthy et al., 2016). Co-administration of quercetin with MSG improved Y-maze discrimination learning and memory. Pu et al. (2007) reported that quercetin ameliorated the neuronal death in the hippocampus leading to enhanced learning and memory. The enhanced learning and memory of Y-maze discrimination could be secondary to the improvement of oxidative stress, anti-inflammatory impact and reduction of AChE.

\section{Conclusion and Recommendation}

From all these results, it is concluded that quercetin had positive effects on brain hippocampus and improved the cognitive impairment in rats treated with MSG by alleviating oxidative stress, suppressing inflammation and maintaining AChE level. During MSG consumption, quercetin may be suggested as a supplement to improve the related neurotoxicity.

\section{Conflict of interest}

There is no conflict of interest.

\section{References}

Abdalla, F.H.; Cardoso, A.M.; Pereira, L.B.; et al. (2013):'Neuroprotective effect of quercetin in ectoenzymes and acetylcholinesterase activities in cerebral cortex synaptosomes of cadmiumexposed rats". Mol. Cell Biochem., 381:1-8. https://doi.org/10.1007/s11010013-1659-x

Abu-Taweel, G.M.; Zyadah, M.; Ajarem, J.S.; et al. (2014): "Cognitive and biochemical effects of monosodium glutamate and aspartame, administered individually and in combination in male albino mice". Neurotoxicol. Teratol., 42: 60-67.

Aebi, H. (1984): "Catalase in vitro, Methods". Enzymol., 105: 121 - 126.

Anand David, A.V.; Arulmoli, R. and Parasuraman, S. (2016): "Overviews of biological importance of quercetin: A bioactive flavonoid". Pharmacogn. Rev., 10: 84-89.

Andersen, J.K. (2004): "Oxidative stress in neurodegeneration: Cause or consequence". Nat. Rev. Neurosci., 10: S18-25.

Bancroft, J. and Gamble, A. (2008): Theory and Practice of Histological Techniques. $5^{\text {th }}$ Edition. Churchil, Living stone, New York and London, P.P. 165-180.

Bandaruk, Y.; Mukai, R. and Terao, J. (2014): "Cellular uptake of quercetin and luteolin and their effects on monoamine oxidase-A in human neuroblastoma SHSY5Y cells". Toxicol. Rep., 1: 639-649.

Bao, D.; Wang, J.; Pang, X.; et al. (2017): "Protective effect of quercetin against oxidative stress-induced cytotoxicity in rat pheochromocytoma (PC-12) cells". Molecules, 22: 11- 22. doi:10.3390/molecules22071122. 
Beutler, E.; Duron, O. and Kelly, B.M. (1963): "Improved method for the determination of blood glutathione". J. Lab. Clin. Med., 61: 882- 888.

Bjorklund, G. and Chirumbolo, S. (2017): "Role of oxidative stress and antioxidants in daily nutrition and human health". Nutrition, 33: 311-321.

Bojanić, V.; Bojanić, Z.; Najman, S.; et al. (2009): "Diltiazem prevention of toxic effects of monosodium glutamate on ovaries in rats". Gen. Physiol. Biophys., 28: 149-154.

Borbély, S.; Détári,L.; Hajnik, T.; et al. (2013): Analysis of behaviour and learning. In: Physiology Practical, P.P. 76-81.

http://www.renderx.com.http://ttktamop. elte.hu/online tananyagok/ physiology_ practical/ch11.html

Compton, D. M. (2004): "Behavior strategy learning in rat: effects of lesions of the dorsal striatum or dorsal hippocampus". Behav. Process., 67: 335-342.

Dief, A.E.; Kamha, E.S.; Baraka, A.M.; et al. (2014): "Monosodium glutamate neurotoxicity increases beta amyloid in the rat hippocampus: a potential role for cyclic AMP protein kinase". Neuro. Toxicolog., 42: 76-82.

El-Beltagi, H.S. and Ahmed, M.M. (2016): "Assessment the protective role of quercetin on acrylamide-induced oxidative stress in rats". Journal of Food Biochemistry, 40 (6): 715-723.

Ellman, G. L. and Callaway, E. (1961): "Erythrocyte cholinesterase-levels in mental patients". Nature, 192: 12-16.

Hashem, H.; Safwat, E.M. and Algaidi, S. (2012): "The effect of monosodium glutamate on the cerebellar cortex of male albino rats and the protective role of vitamin $\mathrm{C}$; histological and immunohistochemical study". J. Mol. Histol., 43 (2): 179- 186.

Hussein, U. K.; Hassan, N. E. Y., Elhalwagy, M. E. A.; et al. (2017): "Ginger and propolis exert neuroprotective effects against monosodium glutamate-induced neurotoxicity in rats". Molecules. 22 (11): 19- 28. doi:

10.3390/molecules22111928.

Joint FAO/WHO Expert Committee on Food Additives (JECFA), (1988): Lglutamic acid and its ammonium, calcium, monosodium and potassium salts. In: Toxicological Evaluation of Certain Food Additives and Contaminants. Cambridge University Press, New York. P. P. 97-161.

Justino, G.C.; Rodrigues, M.; Florencio, M.H.; et al. (2009): "Structure and antioxidant activity of brominated flavonols and flavanones". J. Mass Spectrom., 44 (10): 1459-1468.

Kang, C.H.; Choi, Y.H.; Moon, S.K.; et al. (2013): "Quercetin inhibits lipopolysaccharide-induced nitric oxide production in BV2 microglial cells by suppressing the NF- $\kappa \mathrm{B}$ pathway and activating the Nrf2-dependent HO-1 pathway". Int. Immunopharmacol., 17: 808- 813 .

https://doi.org/10.1016/j.intimp.

Kanter, M.; Unsal, C.; Aktas, C. et al. (2016): "Neuroprotective effect of quercetin against oxidative damage and neuronal apoptosis caused by cadmium in hippocampus". Toxicol. Ind. Health, 32 (3): 541-550.

Khalil, R. M. and Khedr, N. F. (2016): "Curcumin protects against monosodium glutamate neurotoxicity and decreasing NMDA2B and mGluR5 expression in rat hippocampus". Neurosignals, 24: 81-87. 
Lapi, D.; Vagnani, S.; Pignataro, G. et al. (2012): "Protective effects of quercetin on rat pial microvascular changes during transient bilateral common carotid artery occlusion and reperfusion". Front. Physiol., 3:32.

Lu, C. W.; Lin, T. Y. and Wang, S. J. (2013): "Quercetin inhibits depolarization-evoked glutamate release in nerve terminals from rat cerebral cortex". Neurotoxicology, 39: 1- 9. doi: 10.1016/j.neuro.2013.07.009.

Mahmoud, H.M. and Hussein, U.L. (2014): "Suppression of N-nitrosodiethylamine induced oxidative renal toxicity by sulphated polysaccharide and aqueous extract of Ulva lactuca in rats". Int. J. Pharm. Pharm. Sci., 6 (11): 248- 253.

Montgomery, H.A.C. and Dymock, J. F. (1961): "The determination of nitrite in water”. Analyst, 86: 414- 416.

Myhrstad, M.C.; Carlsen, H.; Nordstrom, O.; et al. (2002): "Flavonoids increase the intracellular glutathione level by transactivation of the gamma glutamylcysteine synthetase catalytical subunit promoter". Free Radic. Biol. Med., 32 (5): 386- 393.

Mythri, R. B.; Harish, G. and Bharath, M. M. (2012): "Therapeutic potential of natural products in Parkinson's diseas". Recent Pat. Endocr. Metab. Immune Drug Discov., 6 (3): 181-200.

Ohkawa, H.; Ohishi, N. and Yagi, K. (1979): "Assay for lipid peroxides in animal tissues by thiobarbituric acid reaction". Anal. Biochem., 95 (2): 351358. doi:10.1016/0003-2697(79)90738-3

Onaolapo, O. J.; Onaolapo, A. Y.; Akanmu, M.A.; et al. (2016): "Evidence of alterations in brain structure and antioxidant status following 'low-dose' monosodium glutamate ingestion".
Pathophysiology, 23 (3): 147-156. doi:10.1016/j.pathophys.2016.05.001

Onishi, B.K. and Xavier, G.F. (2010): Contextual, but not auditory, fear conditioning is disrupted by neurotoxic selective lesion of the basal nucleus of amygdala in rats". Neurobiol. Learn. Mem., 93: 165-174.

Park, C.H.; Choi, S.H.; Piaoa, Y.; et al. (2000): "Glutamate and aspartate impair memory retention and damage hypothalamic neurons in adult mice". Toxicol. Lett., 115 (2): 117-125.

Paulke, A.; Schubert-Zsilavecz, M. and Wurglics, M. (2006): "Determination of St. John's wort flavonoid-metabolites in rat brain through high performance liquid chromatography coupled with fluorescence detection". J. Chromatogr. B. Analyt. Technol. Biomed. Life Sci., 832 (1): 109-113.

Pavlovic, V.; Pavlovic, D.; Kocic, G.; et al. (2009): "Ascorbic acid modulates monosodium glutamate induced cytotoxicity in rat thymus". Bratisl. Lek. Listy., 110 (4): 205-209.

Perez-Lloret, S. and Barrantes, F. J. (2016): "Deficits in cholinergic neurotransmission and their clinical correlates in Parkinson's disease". N. P. J. Parkinsons Dis., 2: 16001. doi: 10.1038/npjparkd.2016.1. eCollection 2016.

Pilgrim, L.K.; Murray, J.G.; Donaldson, D.I. (2012): "Characterizing episodic memory retrieval: electrophysiological evidence for diminished familiarity following unitization". J. Cogn. Neurosci., 24: 1671-1681.

Pu, F.; Mishima, K.; Irie, K.; et al. (2007): "Neuroprotective effects of quercetin and rutin on spatial memory impairment in an 8-arm radial maze task and neuronal death induced by repeated cerebral 
ischemia in rats". J. Pharmacol. Sci., 104 (4): 329-334.

Rahvar, M.; Owji, A. A. and Mashayekhi, F. J. (2018): "Effect of quercetin on the brain-derived neurotrophic factor gene expression in the rat brain". Bratisl. Med. J., 119 (1): 28-31.

Sadek, K.; Abouzed, T.; Nasr, S. (2016): "Lycopene modulates cholinergic dysfunction, Bcl-2/Bax balance, and antioxidant enzymes gene transcripts in monosodium glutamate (E621) induced neurotoxicity in a rat model". Can. J. Physiol. Pharmacol., 94 (4): 394 - 401.

Sharma, D.R.; Wani, W.Y.; Sunkaria, A.; et al. (2016): "Quercetin attenuates neuronal death against aluminuminduced neurodegeneration in the rat hippocampus". Neuroscience, 324: 163176.

Sharma, D.R.; Wani, W.Y.; Sunkaria, A.; et al. (2013): "Quercetin protects against chronic aluminum-induced oxidative stress and ensuing biochemical, cholinergic, and neurobehavioral impairments in rats". Neurotox. Res., 23: 336-357.

Shivasharan, B.D.; Nagakannan, P.; Thippeswamy, B.S.; et al. (2013): "Protective effect of Calendula officinalis L. flowers against monosodium glutamate induced oxidative stress and excitotoxic brain damage in rats". Indian J. Clin. Biochem., 28 (3): 292-298.

Singh, R.; Wiseman, B.; Deemagarn, T.; et al. (2008): "Comparative study of catalase-peroxidases (KatGs)". Arch. Biochem. Biophys., 471(2): 207-214. doi: 10.1016/j.abb.2007.12.008.
Suganthy, N.; Devi, K.P.; Nabavi, S.F.; et al. (2016): "Bioactive effects of quercetin in the central nervous system: Focusing on the mechanisms of actions". Biomed. Pharmacother., 84: 892-908.

doi:10.1016/j.biopha.2016.10.011.

Vargas-Restrepo, F.; Sabogal-Guáqueta, A.M. and Cardona-Gómez, G.P. (2018): "Quercetin ameliorates inflammation in CA1 hippocampal region in aged triple transgenic Alzheimer's disease mice model". Biomedica, 38 (0): 69-76. doi:10.7705/biomedica.v38i0.3761

Veni, N.K.; Karthika, D.; Devi, M.S.; et al. (2010): "Analysis of monosodiumglutamate in food products by highperformance thin layer chromatography". J. Young Pharm., 2: 297-300.

Walker, R. and Lupien, J.R. (2000): "The safety evaluation of monosodium glutamate”. J.Nutr., 130: 1049S-1052S.

Yang, E. J.; Kim, G. S.; Kim, J. A.; et al. (2013): "Protective effects of onionderived quercetin on glutamate-mediated hippocampal neuronal cell death". Pharmacogn. Mag., 9 (36): 302-308. doi:10.4103/0973-1296.117824.

Zhang, Y.; Huang, Z.; Yu, L.; et al. (2012): "Protective Effects of tetramethylpyrazine on glutamate-induced neurotoxicity in mice". J. Behav. Brain Sci., 2 (3): 326-332.

http://dx.doi.org/10.4236/jbbs.2012.2303 7.

Zhou, Y. and Danbolt, N. C. (2014): "Glutamate as a neurotransmitter in the healthy brain". J. Neural. Transm. (Vienna), 121(8): 799-817. doi: $10.1007 / \mathrm{s} 00702-014-1180-8$. 


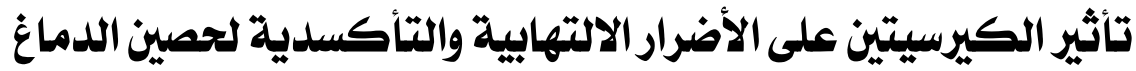

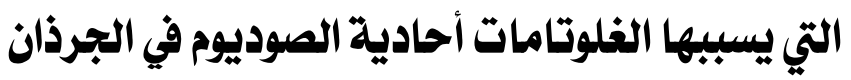

شيرين أحمد الخطيب' ، عبير رمزي محمود' ، نهلة إبراهيه'

\author{
' قسم الطب الثرعي و السموم الاكلينيكية `َقسم علم الأنسجة وبيولوجيا الخلية \\ كلية الطب البشرى - جامعة الزقازيق
}

كـان الهـف مـن الدر اسـة الحاليـة هو بحـث الـدور الوقـائي المحتمـل للكيرسيتين ضـــ الإجهاد التأكسدي و الالتهاب التي تسببهم الجلوتامات أحادية الصوديوم علي الحصين الدماغى لذكور الجرذان البيضاء البالغة. تم تقسيم ثلاثين مـن ذكور الجرذان البـالغين البيـضاء بالتساوي إلى ه مجمو عـات: المجموعـة الأولى

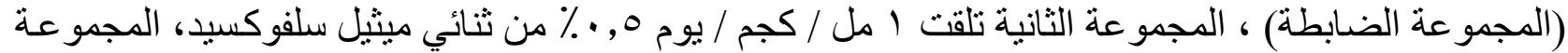

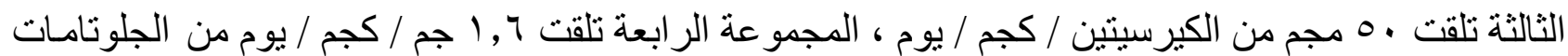

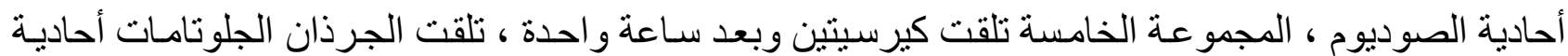
الصوديوم كمـا ذكر سـابقًا. تم إعطاء جميع العلاجـات بـالفم لمدة ثمانية أسـابيع، ثم تم تخدير الفئر ان وذبحها، وأخذت عينات من الحصين لإجر اء در اسات كيميائية ونسيجية.

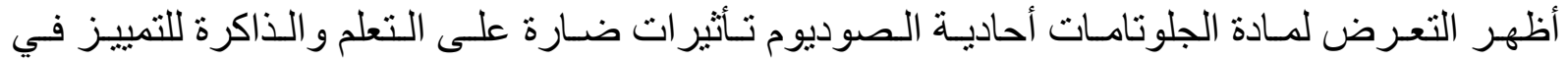
متاهة Y ، وزيادة ملحوظة فى المالونداي الدهيد، مخلقة أكسيد النتريك، و الإنترلوكين ـ ا بيتا ، و عامل نخر

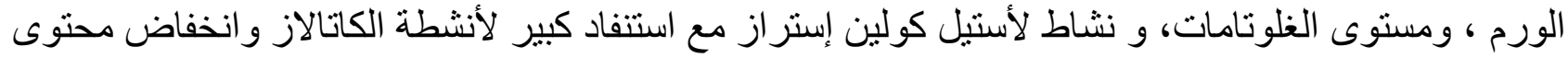
الجلوناثيون. وقد صاحب ذلك تغيير في بنية الحصين. أدى اعطاء الكيرسيتين مـع الجلوتامـات أحادية الصوديوم الى تحسن التأثير ات المذكورة أعلاه.

أظهرت نتائج هذه الدر اسة أن الكيرسيتين له تأثير ات وقائية ضد السمية التي تسببها الجلوتامـات أحاديـة الصوديوم في الحصين في دماغ الجرذان. 